\title{
The Distribution Channel Preferences in Purchase Decision-Making of Backpacker Hostel Customers
}

\author{
Aditia Sovia Pramudita ${ }^{1 *}$; Muhammad Ardhya Bisma ${ }^{2}$; Darfial Guslan ${ }^{3}$ \\ ${ }^{1-3}$ Logistik Bisnis Departemen, Politeknik Pos Indonesia \\ Jln. Sariasih No.54, Bandung 40151, Indonesia \\ 1'aditiasovia@poltekpos.ac.id; ${ }^{2 b i s m a @ p o l t e k p o s . a c . i d ; ~}{ }^{3}$ darfialguslan@poltekpos.ac.id
}

Received: $21^{\text {st }}$ January 2020/ Revised: $11^{\text {th }}$ March 2020/ Accepted: $20^{\text {th }}$ April 2020

How to Cite: Pramudita, A. S., Bisma, M. A., \& Guslan, D. (2020). The Distribution Channel Preferences in Purchase Decision-Making of Backpacker Hostel Customers. Binus Business Review, 11(2), 129-139. https://doi.org/10.21512/bbr. v11i2.6241

\begin{abstract}
The research aimed to find the correlation between distribution channels to each purchase decision-making process in hostel buying. It was aquantitative research using questionnaires to gather the data from 349 respondents. Linear regression analysis was used to analyze the data to find the correlation between each variable. The result shows that Online Travel Agent (OTA) has a significant and positive relationship to every purchase decision-making process. Then, go-show has only a significant and positive correlation in the purchase decision step. Meanwhile, the company's website has a significant and positive relationship to purchase decision and post-purchase behavior steps. Last, the travel agent has no positive correlation to any of the customer decision-making process. Based on those facts, OTA remains the first choice of customers in terms of hostel buying.
\end{abstract}

Keywords: distribution channel, purchase decision-making, backpacker hostel customers

\section{INTRODUCTION}

Indonesia's tourism sector is growing rapidly in recent years. It was shown by the growth in Indonesia's foreign exchange coming from the tourism industry from 2015-2017 around 10,9\% per annum. In 2015-2017, foreign tourists grew about $22 \%$, and the domestic tourist showed a growth of 3,1\% per annum (Badan Pusat Statistik, 2017). The tourism industry becomes one of the priority programs for the government to increase economic development. The tourism industry can develop regional economies besides the industrial sector. Since Indonesia has many beautiful natural resources, it becomes an advantage for the government to be a source of regional income (Setiawan, 2015).

Tourism industry development needs many actors to be run properly. Since the government has already supported the tourism industry, the business player also needs to be functioning properly. Accommodation, as one of the important factors in the tourism industry, needs to be prioritized first (Failte Ireland, 2017). There are many accommodation types for tourists, such as a hotel (1-5 stars), motel, backpacker hostel, campsite, inn, and guest house.

As one of the tourism cities in Indonesia, Bandung is the tourism destination for foreign and domestic tourists. Bandung has many kinds of tourism destinations, such as city tours, local culinary, shopping, and natural resources (Pramudita, 2018). Bandung is also rewarded as the most favorite tourism destination in South East Asia (Hermawan, Widiyanti, Mayangsari, \& Novani, 2018). Those facts show that Bandung can provide a tremendous economic contribution to the government. The growth of foreign tourists in Bandung is $9,74 \%$ per annum, while the domestic tourists are $-5,74 \%$ per annum. Even the domestics growth of domestic tourists declines, the hotel industry in Bandung still increases (Badan Pusat Statistik, 2018).

The accommodation in Bandung increased around 5,78\% per annum from 2009 (Badan Pusat Statistik Provinsi Jawa Barat, 2018). It shows that the hospitality industry in Bandung grows from time to time. Backpacker hostel, as one of the accommodation choices for tourists, also holds an essential role in the growth of the tourism industry. There are different concepts about the backpacker hostel. It is considered 
as accommodation, especially for the student (Iftikhar \& Ajmal, 2015). Meanwhile, others suggest that it is a budget or low-cost accommodation options (Brochado, Rita, \& Gameiro, 2015). In Bandung, it is considered as budget or low-cost accommodation without any demographic preferences. It provides only bed by sharing the room with the other people. This concept is still uncommon in Indonesia. Generally, people do not want to share their room with a stranger. However, this concept is already common in another country to lower accommodation costs (Brenner \& Fricke, 2016). There are already many backpacker hostels in Bandung. Some of them that have a good reputation are Pinisi Backpacker, Pele Backpacker, Buton Backpacker, VK Pods, Bobobox Pods, Garden Hostel, Simplicity Hostel, Capsule Hostel, Chezbon Hostel, and Zenrra Backpacker. Those are located in Bandung city area. Their reputation is shown by the rating and review of the existing customers.

The development of Information and Communications Technology (ICT) in the tourism industry has emerged the term of e-tourism. The use of online media becomes common to promote and sell products or services (Khatri, 2019). There is no doubt that the travel agent has a significant role in the tourism industry (Camilleri, 2018). ICT development has allowed new business model development globally, which also affects the travel agent's business model. In the digital era, there is a terminology which is called Online Travel Agent (OTA). OTA is the development of a traditional travel agent's business model. It becomes the solution for tourism intermediaries in this era. In the digital era, the tourism industry has become a complex global network in which traditional travel agents adapt to the change (Sevrani \& Elmazi, 2008).

Hostel reservations can be made directly and indirectly. Direct reservation is when the guest directly comes to the hostel to book the room. It is also called as go-show (Hendriyati, 2019). Meanwhile, the indirect reservation is by booking the room using third-party travel agents (Bemile, Achampong, \& Danquah, 2014). Nowadays, reservations also can be made via online media directly and indirectly. Direct reservations usually can be made on the company's website, while indirect reservations can be through OTA (Rosyidi, 2019; Pramudita, 2019). There is a report that online reservation is rising especially in Asia Pacific countries, especially in China, India, Indonesia, Singapore, Malaysia, and Thailand (Carroll \& Sileo, 2014). Information Communication Technology (ICT) development in the world has a significant role in changing the condition of business (Pramudita, Yanuar, \& Hilman, 2019). Since ICT is already well developed globally, the online reservation becomes one of the essential factors to be a competitive advantage, especially for the hostel industry. However, online reservations can only be made if the accommodation's owners already put their hostel reservation in online media directly or indirectly. In the case of the hostel, the owners can put the reservation through their website or OTA, such as Traveloka.com, Booking. com, Expedia.com, Agoda.com, Asiarooms.com, and others (Kok \& Teoh, 2013). Online media used to distribute the products or services can be called digital distribution. The digital distribution channel is a way of channeling the product through online media. The performance of online reservations is high. It shows that the digital distribution channel in the hostel industry is considered an essential factor in increasing the sale of hostel rooms.

The customers have preferences toward the selection of the distribution channel. At this time, the use of the digital distribution channel already becomes common. However, many customers are still more comfortable to book a hotel via offline (traditional) distribution channel (Crnojevac, Gugić, \& Karlovčan, 2010). There are various reasons why customers still prefer offline distribution channels. This fact needs to be confirmed in the hostel customers since the hotel and hostel have different customer segmentation.

The distribution channel is a part of the marketing mix in the place section. It determines the distribution strategy of the product to the market. Furthermore, the place in the marketing mix focuses on how to access the product easily. In terms of ICT development, the place plays an essential part in distributing the product to the customers through online media (Carley \& Babb, 2015). The distribution can be divided into direct and indirect. Multi-channel distribution raises the possibility of conflict, and the impact reduces the effectiveness of business performance (Stverkova \& Pohludka, 2018). A direct-distribution channel is when the company directly delivers goods or services to the customers. Meanwhile, an indirect distribution channel is when the company offers the goods or services to the customers through the intermediary party (Mwanza \& Ingari, 2015). The type of direct distribution channel can be seen in the Figure 1 .

In a direct distribution channel, there is no intermediary involved. Information plays an important part in reaching the end customers (Al Badi, 2018). Information distribution can be delivered using many media. The order can be done by phone and delivered by the logistics provider. Nowadays, online selling also can be done directly using the company's website, although the payment system can be a huge problem since the trust becomes the main problem. The company has to ensure that the payment system runs properly (Preetha \& Divya, 2016). It becomes a boundary for small business players to be trusted by their potential customers.

In the indirect channel, intermediary plays an important part, especially in online selling (Yang, 2017). The indirect distribution channel requires an intermediary to make the sale. The intermediary must do the transactional work such as negotiating, dealing, ownership transferring, and taking over the risk. Intermediary also has a role in spreading the distribution network. A good intermediary has an extensive distribution network. The intermediary can be divided into several levels. The intermediary level is the distribution strategy of each company 
(Franco \& Feri, 2017). In the tourism industry, most of the indirect distribution channels are through travel agents, both traditionally or digitally (OTA) (Iazzi, Trio, \& Gravili, 2017).

In the practical implication, changing a trend in distribution channels, especially in the indirect channel, can be a problem for the company since the customers can compare one product with another easily. Furthermore, direct and indirect distribution channels give a different point of view by the customers. Based on research in the hedonic product (tourism package), a direct channel is more preferably than the indirect channel. However, in no doubt, indirect channel distribution adds value to products or services from a range of distribution (Mwanza \& Ingari, 2015). Furthermore, the indirect distribution channel also relatively has less cost than a direct distribution channel (Iazzi et al., 2017). But, the indirect distribution is harder to control than direct distribution channels (Hammoud, Tawfik, \& Fahmy, 2018).

The digital development in the tourism industry has led to the dispersion of OTA (Kim, Franklin, Phillips, \& Hwang, 2020). OTA has merged with hotels to sell their rooms through a digital distribution channel. Hence, the customers' behaviors also change since they can compare prices among OTAs and choose the least expensive one. However, the collaboration between hotels and OTAs still has several problems, such as the low return of investment, lost opportunity, the difficulty of managing commission, and limited service area (Oskam \& Boswijk, 2016). Besides, OTA is not the only one who sells the hotel's room through a digital distribution channel. The hotel also can sell their rooms using their website. This condition creates uncertainty for the hotel's owners that the digital distribution channel needs to be prioritized first.

Next, consumer consciousness is affected by environmental conditions and marketing efforts. This consciousness grows through the psychological process and customers' characteristics. The elaboration process creates the steps for customers when they decide a purchase. The purchase decision-making process can be divided into several steps, which are problem recognition, information search, evaluation of alternatives, purchase decision, and post-purchase behavior (Khuong \& Duyen, 2016).

In Figure 1, problem recognition is the first step in the purchase decision-making process. The purchase decision-making in customers' minds is trigger by an internal or external stimulus (Stankevich, 2017). The next step is the information search. In this step, the customers have recognized their needs and found information for alternatives to the solution. Higher product or service value and lower buying frequency will lead to more thorough information. Vice versa, information is also affected by experience toward product or service (Hussain, 2017). The next step is the evaluation of alternatives. In this step, the customers usually have several alternatives. The degree of evaluation complexity is affected by customers' experiences, the importance of the product or service, cost, and the urgency of the product or service (Gutiérrez Flórez, Correa Escobar, Henao Restrepo, Arango Botero, \& Valencia Arias, 2018). The next step is the purchase decision. The customers have three options (to purchase, not to purchase, and to delay the purchase) and turn it into purchase intention (Khuong \& Duyen, 2016). The decision process is the result of the evaluation of alternatives. The last step is post-purchase behavior. This step can only be experienced by the customers who decide to make a purchase. A post-purchase decision is the customers' paradigm toward the product or service by comparing the expectation and reality (Xu \& Chen, 2017).

The research has an objective to find the correlation between distribution channel preferences toward purchase decision-making of customers in the backpacker hostel. The backpacker hostel owners need to know which distribution channel they need to focus on by considering the limited selling opportunity. Furthermore, most of the owners also do not have significant capital. They have to prioritize their business development due to a lack of capital budget. Moreover, this research also provides a correlation between the distribution channels in every step of the purchase decision-making process. This fact can be used to determine the strategy of the distribution channel of the backpacker hostel in terms of increasing their sales and for academicians for further research.

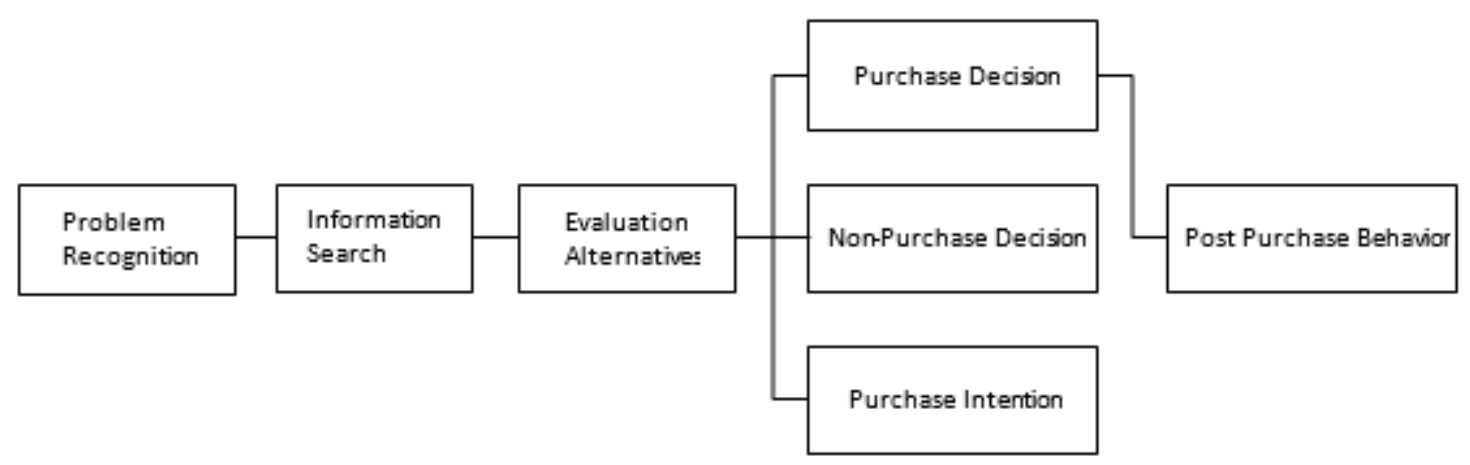

Figure 1 Purchase Decision-Making Process Source: (Stankevich, 2017) 


\section{METHODS}

The explanatory research method is used in the research. It can describe the correlation between distribution channel preferences toward the purchase decision-making process. The population is backpacker hostel customers around Bandung. The population is chosen under the assumption of customers mostly in an urban area. Furthermore, purposive sampling is used to determine the respondents. Sampling is needed since the research can not pursue all population members since it is dynamically changing every day. The number of sampling respondents is 349 respondents with $5 \%$ error rate referring to Isaac and Michael's sampling table (Sugiyono, 2015).

A questionnaire was spread in January until August 2019. The questionnaires were distributed directly (face to face) to backpacker hostel customers by visiting the hostels in the Bandung. Then, the Likert scale is used to determine the score of each question. Likert scale can be treated as ordinal or interval data (Joshi, Kale, Chandel, \& Pal, 2015). In the research, the Likert scale is treated as interval data based on the findings in various research regarding the Likert scale. Since the Likert scale is administered as interval data, a parametric test is used. Multiple linear regression is also used since it determines the correlation between each variable.

Furthermore, the purchase decision-making process utilizes multiple linear regression (Aleksandar, Silvana, \& Valentina, 2015). This method is suitable for determining the purchase decision-making process of customers based on the preferences of distribution channel selection. The backpacker hostel owners can determine the priority of their room sales based on the correlation of distribution channel to purchase decision-making.
The research focuses on finding the correlation between distribution channel preferences toward purchase decision-making. The distribution channel is an independent variable. Meanwhile, purchase decision-making is a dependent variable. The purchase decision-making process is divided into several steps. The hypothesis of the research is the distribution channel influences the steps of the purchase decisionmaking process. In detail, The conceptual framework of this research can be seen in Figure 2, and there are 20 hypotheses as follows:

$\mathrm{H}_{1}$ : company's website has a positive and significant correlation to problem recognition.

$\mathrm{H}_{2}$ : company's website has a positive and significant correlation to information search.

$\mathrm{H}_{3}$ : company's website has a positive and significant correlation to evaluation of alternatives.

$\mathrm{H}_{4}$ : company's website has a positive and significant correlation to purchase decision.

$\mathrm{H}_{5}$ : company's website has a positive and significant correlation to post-purchase behavior.

$\mathrm{H}_{6}$ : go-show has a positive and significant correlation to problem recognition.

$\mathrm{H}_{7}$ : go-show has a positive and significant correlation to information search.

$\mathrm{H}_{8}$ : go-show has a positive and significant correlation to evaluation of alternatives.

$\mathrm{H}_{9}$ : go-show has a positive and significant correlation to purchase decision.

$\mathrm{H}_{10}$ : go-show has a positive and significant correlation to post-purchase behavior.

$\mathrm{H}_{11}$ : OTA has a positive and significant correlation to problem recognition.

$\mathrm{H}_{12}$ : OTA has a positive and significant correlation to information search.

$\mathrm{H}_{13}$ : OTA has a positive and significant correlation to evaluation of alternatives.

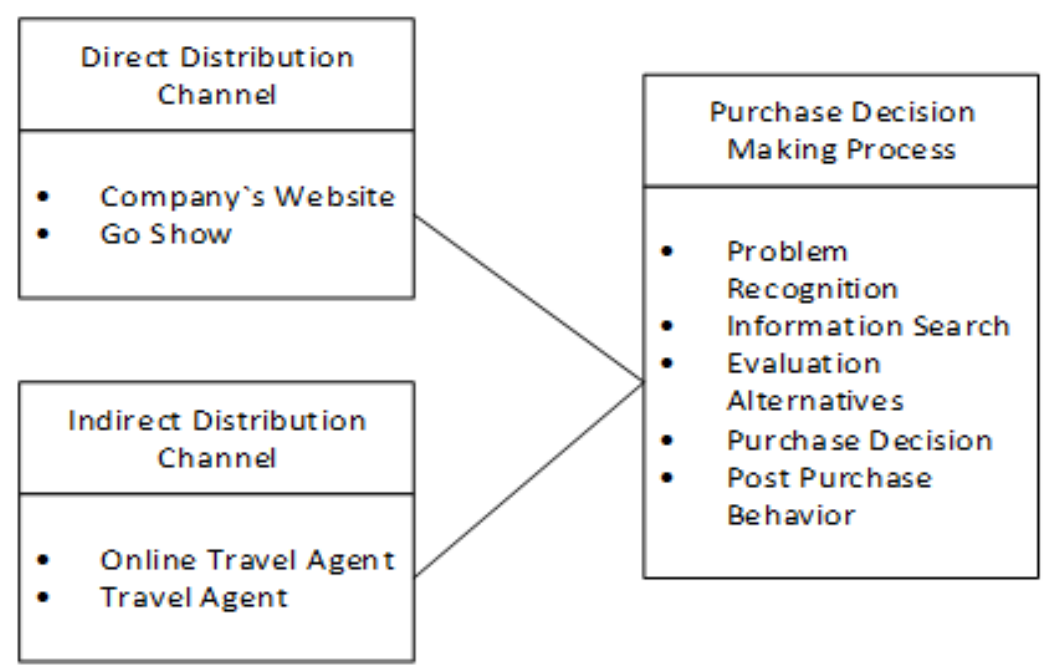

Figure 2 Conceptual Framework 
$\mathrm{H}_{14}$ : OTA has a positive and significant correlation to purchase decision.

$\mathrm{H}_{15}$ : OTA has a positive and significant correlation to post-purchase behavior.

$\mathrm{H}_{16}$ : travel agent has a positive and significant correlation to problem recognition.

$\mathrm{H}_{17}$ : travel agent has a positive and significant correlation to information search.

$\mathrm{H}_{18}$ : travel agent has a positive and significant correlation to evaluation of alternatives.

$\mathrm{H}_{19}$ : travel agent has a positive and significant correlation to purchase decision.

$\mathrm{H}_{20}$ : travel agent has a positive and significant correlation to post-purchase behavior.

The definition of each variable is referring to Kotler and Keller (2009). The operational variable is needed to measure each variable. The operational variable can be seen in Table 1.

\section{RESULTS AND DISCUSSIONS}

Data are collected through questionnaires on a Likert scale. The IBM SPSS 24 software helps data processing. The IBM SPPS 24 is a software to help processing statistics analysis. The researchers commonly use this software. The result is divided based on each step of the purchase decision-making process.

Problem recognition is the first step in the purchase decision-making process. The distribution channel influences problem recognition. This step is when customers define their wants or needs. One of the distribution channel functions is to promote the product or service. The distribution channel can influence customers' needs or wants toward products or services. The determination coefficient of problem recognition to be defined by the distribution channel can be seen in Table 2 .

Table 1 Operational Variables

\begin{tabular}{|c|c|c|c|}
\hline Variable & Dimension & Indicator & Scale \\
\hline \multirow{4}{*}{$\begin{array}{l}\text { Direct Distribution } \\
\text { Channel }\end{array}$} & Company's Website & Product availability (including product variety) & Ordinal \\
\hline & & Ease of obtaining product & Ordinal \\
\hline & Go-Show & Product availability (including product variety) & Ordinal \\
\hline & & Ease of obtaining product & Ordinal \\
\hline \multirow{4}{*}{$\begin{array}{l}\text { Indirect Distribution } \\
\text { Channel }\end{array}$} & OTA & Product availability (including product variety) & Ordinal \\
\hline & & Ease of obtaining product & Ordinal \\
\hline & Travel Agent & Product availability (including product variety) & Ordinal \\
\hline & & Ease of obtaining product & Ordinal \\
\hline \multirow{5}{*}{$\begin{array}{l}\text { Purchase Decision- } \\
\text { Making Process }\end{array}$} & Problem Recognition & $\begin{array}{l}\text { Level of discovering the needs or wants related to a } \\
\text { backpacker hostel }\end{array}$ & Ordinal \\
\hline & Information Search & Level of information related to a backpacker hostel & Ordinal \\
\hline & Evaluation of Alternatives & $\begin{array}{l}\text { Level of alternatives choice related to a backpacker } \\
\text { hostel }\end{array}$ & Ordinal \\
\hline & Purchase Decision & $\begin{array}{l}\text { Level of purchase confidence related to a backpacker } \\
\text { hostel }\end{array}$ & Ordinal \\
\hline & Post-Purchase Behavior & $\begin{array}{l}\text { The eager to give feedback (repurchase, suggestion, } \\
\text { comment, and others) after buying process related to } \\
\text { a backpacker hostel }\end{array}$ & Ordinal \\
\hline
\end{tabular}

Table 2 Determination Coefficient of Problem Recognition

\begin{tabular}{lcccc}
\hline Model & $\mathrm{R}$ & $\mathrm{R}$ Square & Adjusted R-Square & $\begin{array}{c}\text { Std. Error of the } \\
\text { Estimate }\end{array}$ \\
\hline 1 & $0,744^{\mathrm{a}}$ & 0,554 & 0,550 & 0,53035 \\
\hline
\end{tabular}

a. Predictors: (constant), travel agent, company's website, go-show, OTA 
From the result in Table 2, problem recognition can be described $55,4 \%$ by distribution channel preferences while the rest is by other variables. The result of multiple linear regression can be seen in Table 3 . Based on the result, three distribution channels, which are the company's website, go-show, and OTA, have a significant impact on the problem recognition step. However, there is only one distribution channel that has a positive effect on the problem recognition step. It is OTA. The negative impact shows that the correlation is the opposite. In other meaning, if the company's website and go-show increase, their influences in the problem recognition decrease or vice versa. Based on the result, $\mathrm{H}_{1} \mathrm{H}_{6}$, and $\mathrm{H}_{16}$ are rejected. Meanwhile, $\mathrm{H}_{11}$ is accepted. At this stage, the promotion of OTA is very robust. Through promotion, it can attract customers to do traveling. This matter can be a trigger for the customer and convert it into their needs or wants.
Information search is the second step of the purchase decision-making process. This step describes that customers look for various information regarding their needs or wants. The distribution channel is capable of spreading information. In this case, distribution channel selection influences information search in the purchase decision-making process. The determination coefficient of information search can be seen in Table 4. The information search can be described around $52,9 \%$ by distribution channel preferences, while other variables describe the rest. The result of multiple linear regression can be seen in Table 5.

Based on the result in Table 5, only three distribution channels have a significant impact on information search. Those are the company's website, go-show, and OTA. However, there is only one distribution channel that has a positive effect on the information search. It is OTA. The company's

Table 3 Multiple Linear Regression of Problem Recognition

\begin{tabular}{|c|c|c|c|c|c|c|}
\hline \multirow[b]{2}{*}{ Mod } & & \multicolumn{2}{|c|}{ Unstandardized Coefficients } & \multirow{2}{*}{$\begin{array}{c}\begin{array}{r}\text { Standardized } \\
\text { Coefficients }\end{array} \\
\text { Beta }\end{array}$} & \multirow[b]{2}{*}{$\mathbf{t}$} & \multirow[b]{2}{*}{ Sig. } \\
\hline & & B & Std. Error & & & \\
\hline \multirow[t]{5}{*}{1} & (Constant) & 3,468 & 0,370 & & 9,364 & 0,000 \\
\hline & Company's Website & $-0,158$ & 0,020 & $-0,279$ & $-7,693$ & 0,000 \\
\hline & Go-Show & $-0,217$ & 0,036 & $-0,316$ & $-5,997$ & 0,000 \\
\hline & OTA & 0,380 & 0,049 & 0,432 & 7,793 & 0,000 \\
\hline & Travel Agent & 0,000 & 0,049 & 0,000 & 0,004 & 0,997 \\
\hline
\end{tabular}

a. Dependent variable: problem recognition

Table 4 Determination Coefficient of Information Search

\begin{tabular}{lcccc}
\hline Model & R & R Square & Adjusted R Square & Std. Error of the Estimate \\
\hline 1 & $0,727^{\mathrm{a}}$ & 0,529 & 0,525 & 0,56595 \\
\hline
\end{tabular}

a. Predictors: (Constant), travel agent, company's website, go-show, OTA

Table 5 Multiple Regression of Information Search

\begin{tabular}{|c|c|c|c|c|c|c|}
\hline \multirow[b]{2}{*}{ Mod } & & \multirow{2}{*}{\multicolumn{3}{|c|}{$\begin{array}{c}\begin{array}{c}\text { Standardized } \\
\text { Coefficients }\end{array} \\
\text { Beta } \\
\end{array}$}} & \multirow[b]{2}{*}{$\mathbf{t}$} & \multirow[b]{2}{*}{ Sig. } \\
\hline & & & & & & \\
\hline \multirow[t]{5}{*}{1} & (Constant) & 2,860 & 0,395 & & 7,236 & 0,000 \\
\hline & Company's Website & $-0,111$ & 0,022 & $-0,188$ & $-5,059$ & 0,000 \\
\hline & Go-Show & $-0,200$ & 0,039 & $-0,281$ & $-5,188$ & 0,000 \\
\hline & OTA & 0,451 & 0,052 & 0,493 & 8,672 & 0,000 \\
\hline & Travel Agent & 0,039 & 0,052 & 0,033 & 0,755 & 0,450 \\
\hline
\end{tabular}

a. Dependent variable: information search 
website and go-show have a negative impact on the information search. Based on the results, $\mathrm{H}_{2}, \mathrm{H}_{7}$, and $\mathrm{H}_{17}$ are rejected, However, $\mathrm{H}_{12}$ is accepted. It shows that OTA can provide information that customers need to search for a backpacker hostel, while the other distribution channels cannot do.

Evaluation of alternatives is the third step in the purchase decision-making process. Evaluation of alternatives is when the customers eliminate the information into smaller choices. The distribution channel can advise the customers regarding the recommended products or services. It shows that the distribution channel influences evaluation of alternatives step in purchase decision-making. The determination coefficient in the evaluation of alternatives can be seen in Table 6. Based on the result, the evaluation of alternatives can describe $55,4 \%$ of distribution channel preferences. Meanwhile, the rest is explained by other variables. The result of multiple linear regression can be seen in Table 7. Based on the result, there are only three distribution channels that have a significant impact on the evaluation of alternatives. Similarly to the information search, OTA is the only distribution channel that has a positive effect on the evaluation of alternatives step. Meanwhile, company's website and go-show have a negative impact on evaluating alternatives. From the results, $\mathrm{H}_{3}, \mathrm{H}_{8}$, and $\mathrm{H}_{18}$ are rejected. Meanwhile, $\mathrm{H}_{13}$ is accepted. It proves that OTA has numerous options for accommodation. It is considered very helpful for the customer in assessing the options they need.

The purchase decision is the fourth step of the purchase decision-making process. In this step, the customers decide to buy the products or services. The distribution channel can persuade customers to purchase products or services. Customers tend to purchase products or services in their preferable distribution channels. The determination coefficient of purchase decision can be seen in Table 8. Based on the result, purchase decision can explain $42,3 \%$ of distribution channel preferences while other variables describe the rest. The result of multiple linear regression can be seen in Table 9. All of the distribution channels have a significant impact on the purchase decision. However, only three distribution channels have a positive effect on purchase decision steps. Those are the company's website, go-show, and OTA. According to the results, $\mathrm{H}_{4}, \mathrm{H}_{9}$, and $\mathrm{H}_{14}$ are accepted. Then, $\mathrm{H}_{19}$ is rejected. It means that company's website, goshow, and OTA can persuade a customer to purchase. Meanwhile, the travel agent has a negative impact on the purchase decision.

Table 6 Determination Coefficient of Evaluation of Alternatives

\begin{tabular}{lcccc}
\hline Model & R & R Square & Adjusted R Square & Std. Error of the Estimate \\
\hline 1 & $0,744^{\mathrm{a}}$ & 0,554 & 0,551 & 0,54627 \\
\hline
\end{tabular}

a. Predictors: (Constant), travel agent, company's website, go-show, OTA

Table 7 Multiple Regression Linear of Evaluation of Alternatives

\begin{tabular}{|c|c|c|c|c|c|c|}
\hline \multirow{2}{*}{ Model } & \multirow[b]{2}{*}{ B } & \multicolumn{2}{|c|}{ Unstandardized Coefficients } & \multirow[t]{2}{*}{ Standardized Coefficients } & \multirow[b]{2}{*}{$\mathbf{t}$} & \multirow[b]{2}{*}{ Sig. } \\
\hline & & Std. Error & Beta & & & \\
\hline \multirow[t]{5}{*}{1} & (Constant) & 3,013 & 0,381 & & 7,899 & 0,000 \\
\hline & $\begin{array}{l}\text { Company's } \\
\text { Website }\end{array}$ & $-0,137$ & 0,021 & $-0,235$ & $-6,498$ & 0,000 \\
\hline & Go-Show & $-0,178$ & 0,037 & $-0,252$ & $-4,784$ & 0,000 \\
\hline & OTA & 0,452 & 0,050 & 0,499 & 9,010 & 0,000 \\
\hline & Travel Agent & 0,001 & 0,050 & 0,001 & 0,024 & 0,981 \\
\hline
\end{tabular}

a. Dependent variable: evaluation of alternatives

Table 8 Determination Coefficient of Purchase Decision

\begin{tabular}{lcccc}
\hline Model & R & R Square & Adjusted R Square & $\begin{array}{c}\text { Std. Error of the } \\
\text { Estimate }\end{array}$ \\
\hline 1 & $0,650^{\mathrm{a}}$ & 0,423 & 0,418 & 0,35779 \\
\hline
\end{tabular}

a. Predictors: (Constant), travel agent, company's website, go-show, OTA 
Post-purchase behavior is the fifth step in the purchase decision-making process. It is when the customers act after the purchasing process. For example, customers repurchase the product or services; or give reviews toward the products or services. The selection of distribution channels can encourage post-purchase behavior. It shows that the distribution channel influences post-purchase behavior. The determination coefficient of post-purchase behavior can be seen in Table 10 .

From the result in Table 10, post-purchase behavior can be described by about $67,1 \%$ of distribution channel preferences. The rest is by other variables. The result of multiple linear regression can be seen in Table 11. Like the previous step, all of the distribution channels have a significant impact on post- purchase behavior. However, only two distribution channels have a positive effect on post-purchase behavior, namely the company's websites and OTA. Go-show and travel agents have a negative impact on post-purchase behavior. Based on the results, $\mathrm{H}_{5}$ and $\mathrm{H}_{15}$ are accepted. Meanwhile, $\mathrm{H}_{10}$ and $\mathrm{H}_{20}$ are rejected. This step can be related to the usage of online media. When customers deal through online media, they tend to ask customers for reviews.

Customers' preferences on distribution channel selection have an impact on every step of the purchase decision-making process. Furthermore, a positive or negative correlation also needs to be reconsidered. Negative correlation should not be considered necessary since the correlation is the opposite. The conclusion of this research can be seen in Table 12 .

Table 9 Multiple Linear Regression of Purchase Decision

\begin{tabular}{|c|c|c|c|c|c|c|}
\hline \multicolumn{2}{|c|}{ Model } & \multicolumn{2}{|c|}{ Unstandardized Coefficients } & \multirow{2}{*}{$\begin{array}{c}\begin{array}{c}\text { Standardized } \\
\text { Coefficients }\end{array} \\
\text { Beta }\end{array}$} & \multirow[b]{2}{*}{$\mathbf{t}$} & \multirow[b]{2}{*}{ Sig. } \\
\hline & & B & Std. Error & & & \\
\hline \multirow[t]{5}{*}{1} & (Constant) & 2,839 & 0,250 & & 11,364 & 0,000 \\
\hline & $\begin{array}{l}\text { Company's } \\
\text { Website }\end{array}$ & 0,200 & 0,014 & 0,596 & 14,449 & 0,000 \\
\hline & Go-Show & 0,271 & 0,024 & 0,665 & 11,076 & 0,000 \\
\hline & OTA & 0,077 & 0,033 & 0,147 & 2,329 & 0,020 \\
\hline & Travel Agent & $-0,324$ & 0,033 & $-0,479$ & $-9,874$ & 0,000 \\
\hline
\end{tabular}

a. Dependent variable: purchase decision

Table 10 Determination Coefficient of Post Purchase Behavior

\begin{tabular}{lcccc}
\hline Model & R & R Square & Adjusted R Square & $\begin{array}{c}\text { Std. Error of the } \\
\text { Estimate }\end{array}$ \\
\hline 1 & 0,819 & 0,671 & 0,669 & 0,86264 \\
\hline
\end{tabular}

a. Predictors: (Constant), travel agent, company's website, go-show, OTA

Table 11 Multiple Linear Regression of Post Purchase Behavior

\begin{tabular}{|c|c|c|c|c|c|c|c|}
\hline \multirow[b]{2}{*}{ Mod } & & \multicolumn{2}{|c|}{ Unstandardized Coefficients } & \multicolumn{2}{|c|}{ Standardized Coefficients } & \multirow[b]{2}{*}{$\mathbf{t}$} & \multirow[b]{2}{*}{ Sig. } \\
\hline & & B & Std. Error & Beta & & & \\
\hline \multirow[t]{5}{*}{1} & (Constant) & 2,715 & 0,602 & & & 4,507 & 0,000 \\
\hline & $\begin{array}{l}\text { Company's } \\
\text { Website }\end{array}$ & 0,104 & 0,033 & & 0,097 & 3,114 & 0,002 \\
\hline & Go-Show & $-0,550$ & 0,059 & & $-0,423$ & $-9,338$ & 0,000 \\
\hline & OTA & 0,628 & 0,079 & & 0,376 & 7,921 & 0,000 \\
\hline & Travel Agent & $-0,196$ & 0,079 & & $-0,090$ & $-2,473$ & 0,014 \\
\hline
\end{tabular}

a. Dependent variable: post purchase behavior 
Table 12 Result Conclusion

\begin{tabular}{|c|c|c|c|c|}
\hline & \multicolumn{2}{|c|}{ Direct Distribution Channel } & \multicolumn{2}{|c|}{ Indirect Distribution Channel } \\
\hline & Company's Website & Go-Show & OTA & Travel Agent \\
\hline $\begin{array}{l}\text { Problem } \\
\text { Recognition }\end{array}$ & $\begin{array}{l}\text { Significant but negative } \\
\text { correlation }\left(\mathrm{H}_{1} \text { is rejected }\right)\end{array}$ & $\begin{array}{l}\text { Significant but negative } \\
\text { correlation }\left(\mathrm{H}_{6} \text { is rejected }\right)\end{array}$ & $\begin{array}{l}\text { Significant and positive } \\
\text { correlation }\left(\mathrm{H}_{11} \text { is accepted }\right)\end{array}$ & $\begin{array}{l}\text { Insignificant }\left(\mathrm{H}_{16} \text { is }\right. \\
\text { rejected })\end{array}$ \\
\hline $\begin{array}{l}\text { Information } \\
\text { Search }\end{array}$ & $\begin{array}{l}\text { Significant but negative } \\
\text { correlation }\left(\mathrm{H}_{2} \text { is rejected }\right)\end{array}$ & $\begin{array}{l}\text { Significant but negative } \\
\text { correlation }\left(\mathrm{H}_{7} \text { is rejected }\right)\end{array}$ & $\begin{array}{l}\text { Significant and positive } \\
\text { correlation }\left(\mathrm{H}_{12} \text { is accepted }\right)\end{array}$ & $\begin{array}{l}\text { Insignificant }\left(\mathrm{H}_{17} \text { is }\right. \\
\text { rejected })\end{array}$ \\
\hline $\begin{array}{l}\text { Evaluation of } \\
\text { Alternatives }\end{array}$ & $\begin{array}{l}\text { Significant but negative } \\
\text { correlation }\left(\mathrm{H}_{3} \text { is rejected }\right)\end{array}$ & $\begin{array}{l}\text { Significant but negative } \\
\text { correlation }\left(\mathrm{H}_{8} \text { is rejected }\right)\end{array}$ & $\begin{array}{l}\text { Significant and positive } \\
\text { correlation }\left(\mathrm{H}_{13} \text { is accepted }\right)\end{array}$ & $\begin{array}{l}\text { Insignificant }\left(\mathrm{H}_{18} \text { is }\right. \\
\text { rejected })\end{array}$ \\
\hline $\begin{array}{l}\text { Purchase } \\
\text { Decision }\end{array}$ & $\begin{array}{l}\text { Significant and positive } \\
\text { correlation }\left(\mathrm{H}_{4} \text { is accepted }\right)\end{array}$ & $\begin{array}{l}\text { Significant and positive } \\
\text { correlation }\left(\mathrm{H}_{9} \text { is accepted }\right)\end{array}$ & $\begin{array}{l}\text { Significant and positive } \\
\text { correlation }\left(\mathrm{H}_{14} \text { is accepted }\right)\end{array}$ & $\begin{array}{l}\text { Significant but negative } \\
\text { correlation }\left(\mathrm{H}_{19} \text { is }\right. \\
\text { rejected })\end{array}$ \\
\hline $\begin{array}{l}\text { Post-Purchase } \\
\text { Behavior }\end{array}$ & $\begin{array}{l}\text { Significant and positive } \\
\text { correlation }\left(\mathrm{H}_{5} \text { is accepted }\right)\end{array}$ & $\begin{array}{l}\text { Significant but negative } \\
\text { correlation }\left(\mathrm{H}_{10} \text { is rejected }\right)\end{array}$ & $\begin{array}{l}\text { Significant and positive } \\
\text { correlation }\left(\mathrm{H}_{15} \text { is accepted }\right)\end{array}$ & $\begin{array}{l}\text { Significant but negative } \\
\text { correlation }\left(\mathrm{H}_{20} \text { is }\right. \\
\text { rejected })\end{array}$ \\
\hline
\end{tabular}

Based on distribution channel preferences, OTA is considered as the best distribution channel to promote the hostel. It has numerous advantages compared to other distribution channels. It gives numerous information that is considered as useful for customers, especially backpacker hostel customers. In indirect distribution channel, there is another distribution channel which is a travel agent. Based on the research, travel agent is considered unsuitable in selling backpacker hostel rooms. Even though the traditional travel agents have more information than a direct distribution channel, they are not preferable in the purchase decision-making process for backpacker hostel customers. The company's website is the best distribution channel in the direct distribution channel since it is related to two steps of the purchase decisionmaking process: purchase decision and post-purchase behavior. Meanwhile, go-show only has an impact on the purchase decision. It makes sense since go-show guests generally purchase the room in compulsion or unplanned moment.

The researchers recommend OTA as a priority of backpacker hostel distribution as an indirect distribution channel. Furthermore, the owners should consider building their website as a direct distribution channel to sell their room. In the end, the digital distribution channel has an essential part in selling rooms. The result matches another research in which backpacker hostel segmentation is considered for young customers who are already familiar with online distribution channels (Brenner \& Fricke, 2016). Furthermore, Brenner and Friceke (2016) found that choosing a backpacker hostel to stay already became a lifestyle in several countries. Backpacker hostel offered a different experience than the hotel. Based on those findings, the behavior of the young customer is essential to the backpacker hostel. Since young customers are the main segmentation in the backpacker hostel, digital media become their main source of information (Pramudita et al., 2019; Pearce, Tan, \& Schott, 2003). It shows that digital distribution channels become an essential part of selling rooms to young customers. The result is different from Hiransomboon (2012), who stated that agency (not reported either an offline travel agent or OTA) and go-show were preferable distribution channels for backpacker hostel customers. Hiransomboon (2012) showed that tourists in Bangkok, Thailand, preferred go-show to ensure that the place for staying was suitable for their needs and wants. By doing go-show, they could negotiate the price. However, the research shows that go-show is not preferable since, in Bandung, the number of backpacker hostels is limited. Besides, the backpacker hostel's concept is still uncommon in Indonesia.

\section{CONCLUSIONS}

The distribution channel influences every step of the purchase decision-making process. However, only OTA correlates with all steps of the purchase decision-making process. A traditional travel agent is considered less important in the purchase decisionmaking process. Furthermore, the company's website is also an important distribution channel for the backpacker hostel since it can affect dimensions of the purchase decision and post-purchase behavior. Go-show also affects one dimension of the purchase decision-making process, which is the purchase decision.

In conclusion, backpacker hostel practitioners should prioritize selling through OTA, such as Traveloka, Hostelworld, Booking.com, Tiket.com, Agoda.com, and others. Then, the company's website also needs to be developed since it is considered important for this customer. Last, the backpacker hostel practitioners still need to spare some rooms 
to go-show customers. Based on the research result, go-show also is considered an important distribution channel.

The research is limited to the greater area in Bandung only. In future research, it can be spread to another big tourist destination city such as Jakarta, Yogyakarta, Bali, Medan, Batam, Surabaya, and Makasar. In there, people are already familiar with the hostel concept as accommodation.

\section{REFERENCES}

Al Badi, K. S. (2018). The impact of marketing mix on the competitive advantage of the SME sector in the Al Buraimi Governorate in Oman. SAGE Open, 8(3), $1-10$.

Aleksandar, P., Silvana, P., \& Valentina, Z. P. (2015). Multiple linear regression model for predicting bidding price. Technics Technologies Education Management (TTEM), 10(3), 386-393.

Badan Pusat Statistik. (2017). Kajian data pasar wisatawan nusantara. Retrieved from http://www. kemenparekraf.go.id/asset_admin/assets/uploads/ media/pdf/media_1553500574_Publikasi_Kajian_ Data_Pasar_Wisnus 2017.pdf

Badan Pusat Statistik. (2018). Jumlah wisatawan mancanegara dan domestik di kota Bandung. Retrieved from https://bandungkota.bps.go.id/ statictable/2017/08/29/120/jumlah-wisatawanmancanegara-dan-domestik-di-kota-bandung-2016. html

Badan Pusat Statistik Provinsi Jawa Barat. (2018). Jumlah hotel dan akomodasi lainnya, kamar, dan tempat tidur di Jawa Barat. Retrieved from https://jabar. bps.go.id/statictable/2015/04/02/45/jumlah-hoteldan-akomodasi-lainnya-kamar-dan-tempat-tidur-dijawa-barat-2009-2013.html

Bemile, R., Achampong, A., \& Danquah, E. (2014). Online hotel reservation system. International Journal of Innovative Science, Engineering \& Technology, 1(9), 583-588.

Brenner, L., \& Fricke, J. (2016). Lifestyle entrepreneurs, hostels and backpacker tourism development: The case of San Cristóbal de las Casas, Mexico. El Periplo Sustentable: Revista de turismo, desarrollo y competitividad, 2016(31), 1-21.

Brochado, A., Rita, P., \& Gameiro, C. (2015). Exploring backpackers' perceptions of the hostel service quality. International Journal of Contemporary Hospitality Management, 27(8), 1839-1855.

Camilleri, M. A. (2018). The tourism industry: An overview. In Travel marketing, tourism economics and the airline product: An introduction to theory and practice (Chapter 1, pp. 3-27). Cham: Springer.

Carley, M., \& Babb, J. S. (2015). A match in the making: How emergent changes in the marketing discipline present opportunities for information systems programs. Information Systems Education Journal, 13(6), 54-67.

Carroll, B., \& Sileo, L. (2014). Online travel agencies:
More than a distribution channel. New York: PhoCusWright.

Crnojevac, I. H., Gugić, J., \& Karlovčan, S. (2010). eTourism: A comparison of online and offline bookings and the importance of hotel attributes. Journal of Information and Organizational Sciences, 34(1), 41-54.

Failte Ireland. (2017). Wider benefits of tourist accommodation. Retrieved from https://failteireland. ie/FailteIreland/media/WebsiteStructure/ Documents/3_Research_Insights/3_General_ SurveysReports/Failte-Ireland-Wider-Benefits-ofTourist-Accommodation.pdf

Gutiérrez Flórez, L. E., Correa Escobar, M. I., Henao Restrepo, A., Arango Botero, D., \& Valencia Arias, A. (2018). Influence of social networks on the purchase decisions of university students. Cuadernos de Gestión, 18(1), 61-84.

Franco, A., \& Feri, R. F. (2017). Utilization of banks as distribution channels by asset management companies in Indonesia. International Journal of Research in Business Studies and Management, 4(4), 1-7.

Hammoud, G. A., Tawfik, H. F., \& Fahmy, R. S. (2018). Development of airlines' distribution capabilities. Journal of Tourism and Hospitality Management, $6(1), 66-80$.

Hendriyati, L. (2019). Pengaruh online travel agent terhadap pemesanan kamar di Hotel Mutiara Malioboro Yogyakarta. Media Wisata, 17(1), 1-10.

Hermawan, P., Widiyanti, R., Mayangsari, L., \& Novani, S. (2018). Urban tourism development for Bandung City, Indonesia: A preliminary study. International Journal of Business \& Society, 19(1), 73-86.

Hiransomboon, K. (2012). Marketing mix affecting accommodation service buying decisions of backpacker tourist traveling at Inner Rattanakosin Island in Bangkok, Thailand. Procedia Economics and Finance, 3, 276-283.

Hussain, M. (2017). Study on consumer decision making process in the selection of home cleaning company: Case company: MHB Clean Helsinki (Bachelor's thesis). JAMK University of Applied Sciences.

Iazzi, A., Trio, O., \& Gravili, S. (2017). Hotels and online travel agencies: Power or trust for a competitive long-term relationship. International Journal of Technology Marketing, 12(2), 115-126.

Iftikhar, A., \& Ajmal, A. (2015). A qualitative study investigating the impact of hostel life. International Journal of Emergency Mental Health and Human Resilience, 17(2), 511-515.

Joshi, A., Kale, S., Chandel, S., \& Pal, D. K. (2015). Likert scale: Explored and explained. British Journal of Applied Science \& Technology, 7(4), 396-403.

Khatri, I. (2019). Information technology in tourism \& hospitality industry: A review of ten years' publications. Journal of Tourism and Hospitality Education, 9, 74-87.

Khuong, M. N., \& Duyen, H. T. M. (2016). Personal factors affecting consumer purchase decision towards men skin care products-A study in Ho Chi Minh city, 
Vietnam. International Journal of Trade, Economics and Finance, 7(2), 44-50.

Kim, J., Franklin, D., Phillips, M., \& Hwang, E. (2020). Online travel agency price presentation: Examining the influence of price dispersion on travelers' hotel preference. Journal of Travel Research, 59(4), 704721.

Kok, A. L. M., \& Teoh, B. W. (2013). Exploring consumers' attitudes and behaviours toward online hotel room reservations. American Journal of Economics, 3(5C), 6-11.

Kotler, P., \& Keller, K. L. (2009). Marketing management. Upper Saddle River, NJ: Pearson Prentice Hall.

Mwanza, P., \& Ingari, B. (2015). Strategic role of distribution as a source of competitive advantage in fast-moving consumer goods in Kenya. International Journal of Scientific and Research Publications, 5(4), 54-67.

Oskam, J., \& Boswijk, A. (2016). Airbnb: The future of networked hospitality businesses. Journal of Tourism Futures, 2(1), 22-42.

Pearce, D., Tan, R., \& Schott, C. (2003). Distribution channels for urban tourism: Issues and examples from Wellington, New Zealand. In Travel and Tourism Research Association Europe Conference.

Pramudita, A. S. (2018). Formulasi model bisnis hostel di Bandung dengan pendekatan value chain dan business model canvas (Studi kasus: Pinisi Backpacker). ISEI Business and Management Review, 2(1), 32-38.

Pramudita, A. S. (2019). Pengukuran performa digital distribution channel terhadap keputusan pembelian hostel pada Pinisi Backpacker dengan multinomial logistic regression. Competitive, 14(2), 1-8.

Pramudita, A. S., Yanuar, A., \& Hilman, T. (2019). Business model formulation for e-newspaper in Indonesia (Case study: Pikiran Rakyat). Jurnal Bisnis dan Manajemen, 20(1), 15-31.
Preetha, S., \& Divya, V. (2016). Customers trust on the security of online payment system using credit/ debit cards with reference to banking customers in Chennai. American International Journal of Research in Humanities Arts and Social Sciences, 15(1), 79-84.

Rosyidi, M. I. (2019). Indonesian online travel agencies: Profiling the services, employment, and users. In $3^{\text {rd }}$ International Seminar on Tourism (ISOT 2018).

Setiawan, I. (2015). Potensi destinasi wisata di Indonesia menuju kemandirian ekonomi. In Prosiding Seminar Nasional Multi Disiplin Ilmu \& Call For Papers UNISBANK (SENDI U).

Sevrani, K., \& Elmazi, L. (2008). ICT and the changing landscape of tourism distribution-A new dimension of tourism in the global conditions. Revista de Turism-Studii si Cercetari in Turism/ Journal of Tourism - Studies and Research in Tourism, 6(6), 2229.

Stankevich, A. (2017). Explaining the consumer decisionmaking process: Critical literature review. Journal of International Business Research and Marketing, 2(6), 7-14.

Stverkova, H., \& Pohludka, M. (2018). Business organisational structures of global companies: Use of the territorial model to ensure long-term growth. Social Sciences, 7(6), 1-9.

Sugiyono (2015). Metode penelitian kombinasi (Mix methods). Bandung: Alfabeta.

Xu, B., \& Chen, J. (2017). Consumer purchase decisionmaking process based on the traditional clothing shopping form. Journal of Fashion Technology \& Textile Engineering, 5(3), 1-12.

Yang, Q. (2017). Third-party online payment solutions in China: Case study: Alipay (Bachelor's Thesis). Lahti University of Applied Sciences. 